\title{
QUEERING TIME THROUGH THE MYTH OF THE FALL IN MARCEL PROUST'S SODOM AND GOMMORAH
}

\author{
Iva Dimovska \\ Central European University, Budapest \\ Dimovska_Iva@phd.ceu.edu
}

In this paper I analyze the queering of time in Marcel Proust's novel Sodom and Gomorrah, the fourth volume of In Search of Lost Times, focusing on the role the myth of the Fall plays as a catalyst of this process. I argue that the ambiguous intertwining of temporality and sexuality introduced by the myth of the Fall through the narration of Sodom and Gomorrah structures the narrativization of sexuality and temporality in the novel. In my analysis, queer times in Proust's novel emerge at those instances when non-normative desires and practices result in the complexification of the dimensions of time. The inducement of temporal dissonance through queer forms of sexuality and sociability as motivated by the failure the Fall brings is done through writing. In this essay, the act of writing for Proust is addressed as a dimension of queer time.

Keywords: queer theory, modernism, failure, mythology, negativity 


\section{КВИР-ВРЕМЕТО И МИТОТ ЗА ПАДОТ ВО СОДОМА И ГОМОРА ОД МАРСЕЛ ПРУСТ}

Ива Димовска

Централноевропски универзитет, Будимпешта

Dimovska_Iva@phd.ceu.edu

Овој есеј ја истражува тематиката на квир-времето во романот Содома $u$ Гомора од Марсел Пруст, четвртиот том од Во потрага по изгубеното време, фокусирајќи се на Митот за падот и неговата улога како катализатор што го води овој процес. Амбивалентното преплетување на темпоралноста и сексуалноста, воведено од Митот за падот преку наративот за Содома и Гомора, ја структурира наративизацијата на сексуалноста и темпоралноста во овој роман. Квир-времето функционира како категорија на анализа во романот на Пруст, бидејќи ненормативните сексуални желби и практики влијаат врз репрезентацијата на наративниот елемент време. Темпоралната дисонанција, искажана преку квир-формите на сексуалност и на социјабилност, е резултат од „неуспехот“, содржан во Митот за падот, кој тука се реализира преку чинот на пишување. Во овој есеј чинот на пишување за Пруст е анализиран како димензија на квир-времето.

Клучни зборови: квир-теорија, модернизам, неуспех, митологија, негативHост 


\section{Intersecting Modernist and Queer Temporalities}

The concern with time has repeatedly been considered one of the essential characteristics of modernity and as such, has greatly informed modernist literature at the turn of the nineteenth to the twentieth century. ${ }^{1}$ Around one hundred years later, at the turn of the twentieth to the twenty-first century, the linearity of temporality is being reexamined in a very similar fashion by queer theory scholars ${ }^{2}$. Firstly, a few sentences on my use of "queer" will help in clarifying my methodology of approach. Although "queer" is used most often to denote same-sexual desires and practices, at the same time it tends to overpass the spheres of gender and sexuality. ${ }^{3}$ The diverse potentials of "queering" I have in mind when referring to the multiplicity of meanings conjoined in the term can be depicted when queer is understood as "an open mesh of possibilities, gaps, overlaps, dissonances and resonances, lapses and excesses" that oppose and subvert the heteronormative, conventional, linear aspects and ways of life (Kosofsky Sedgwick 1993: 8). It is exactly this axis of thought that enables the intertwinement of "queer" and "mythic" or "modernist" temporalities in a revised understanding of time which focuses not on its chronological linearity, but instead, argues for alternative, queer times that "inaugurate, create, proliferate, shift social relations" (Freeman 2007:188).

At the center of this essay lies my premise that modernism's obsession with nonlinear time and queer theory's urge for examination of temporal and sexual normativity share profound methodological, theoretical, and narrative similarities. And although there are many ways in which these similarities can be and have been approached, I will focus on the formative role failure has for this conjunction. In other words, in looking for connections between the conceptualizations of queer and modernist time, and their relationship to the notion of human fallibility as evoked by Fall pattern, I invoke the concept of failure as a prominent notion in the field of queer studies, and use it as methodological approach that enables the comparison. Relying of works by queer theory scholars José Esteban Muñoz and Lee Edelman and their queer analysis of the temporal ramifications of negativity/utopia, I interpret the notion of failure as contained in the Fall pattern as a generator of feelings of jealousy, loss, trauma, suffering; but at the same time as a means which can produce alternative forms of temporality, sociability and relationality. Failure is perceived here as a source for productive reinventions of both sexual and temporal experiences.

\section{Intertwining Sexualities and Temporalities through the Myth of the Fall}

In its most elemental narrative form, the myth of the Fall has been often described as representing the most universal human experiences: the desire for tasting the forbidden followed by the everlasting consequences of pain, suffering and regrets it

\footnotetext{
${ }^{1}$ See more in: Barrows 2010: 1, Bauman 2000: 172, Kern 2003: 4-5.

${ }^{2}$ See more in: Freeman 2007: 177-195, Eng, Halberstam, Muñoz 2005: 1-17.

${ }^{3}$ At the same time, as a manner of maintaining queer's sexual connotations in this context, I use the term interchangeably with "homosexual".
} 
causes. Two interpretative traditions have centered around the Fall motif. The first one, mostly held by early Christian theologians and philosophers emphasizes man's hubris that has caused the unfortunate and painful fall.

But, as Mircea Eliade points out, "the myth of the 'fall' has not always been understood in accordance with its biblical interpretations. Especially from the Hellenistic period and down to the time of illuminism, countless speculations have sought to elaborate a more daring, and often more original, Adamic mythology" (see 1987: 1:167). Joseph Campbell, in the third volume of his famous work "The Masks of God" entitled Occidental Mythology, is following the remnants of diverse mythological fall stories in their biblical equivalents. He is one of the authors who offer an alternative reading of the biblical episode of the Fall. "There is no Fall, no sense of sin or exile, in the primitive examples. They are affirmative, not critical, of life" (1962: 3:105). Therefore, the second interpretive tradition comprehends Adam and Eve's fall as the event that has initiated the existence of life's realities that otherwise would not be known to humanity.

Time, together with the desire for knowledge, self-discovery and the experience of sexuality, is one of the many benefits acquired after this "Felix culpa", "fortunate sin" or "happy fault/fall". "The phenomenological universe of time and space is a consequence of the Fall" (Otten 1982:18). Falling from a harmonious paradisiacal state into imbalance, dissociation, fragmentation and chaos, man falls also into an awakening of consciousness, self-knowledge, criticism and reflexivity, as well as into a discovery of sexual desires and libidinal energy. After the great Fall man and woman fall within themselves and in the Other, in and through Time. Thus, the Fall is a sexual and a temporal event. The awakening that both the man and the woman experience does not only "open their eyes", enabling them to recognize good from evil as the Genesis verse indicates, and bestowing upon them the gift of intelligence, but is also sexual initiation (King James Bible, Genesis 3.5). The myth of the Adam and Eve's fall is not just a consequence of their newly acquired ability to distinguish between good and evil, but it is also the result of their tasting the "forbidden fruit", often deeply embedded in sexual imagery (Dillistone 1965:351). The loss of their innocence is thus also a punishment for the committed sexual crime. Paradoxically, their transgression of the laws of God also leads to the emergence of sexual pleasures.

The awakening of sexuality through the Fall transforms the primordial, mythical, eternal or "timeless" time into a multidimensional timeline, consisting of past, present and future as separate dimensions. Furthermore, the Fall not only initiates the beginning of "real" time, but being the twofold event that it is, also announces the end of time, both personal and historic. Thus, the Fall pattern introduces the complexity of temporality into human life through the awakening of sexuality in the affectual sphere of guilt, shame and sin. Starting from here, I propose an approach that treats the myth of the Fall as a device that enables the amalgamation of past, present and future and by doing that, creates a sphere in which they can interact in endless ways. But what drives my analysis here is not only the diversification of temporal dimensions the Fall induces, but also the role sexuality plays in that process. 
Therefore, in this essay, I analyze the ways in which through his own rendering of the Fall pattern in Sodom and Gomorrah (1921/22), the fourth volume of the canonical modernist novel In Search of Lost Time (originally published in French between 1913-1927), Marcel Proust developed a sphere in which the past, present and future intertwine through the invocation of sexually transgressive experiences. As outlined above, by doing that I rely on the very productive intersection between modernist and queer temporalities, by positing the concept of queer failure at the center of my analysis. I start by briefly analyzing how the myth of the destruction of Sodom and Gomorrah that engenders sexual, as well as temporal dissonance, can be read as another instance of the Fall motif.

\subsection{The fall of Sodom and Gomorrah}

Sodom and Gomorrah are two of the five Cities of the Plain (together with Admah, Zeboiim and Zoar). They are firstly mentioned in the Old Testament in Genesis 10, as the geographical locations inhabited by the generations of the sons of Noah. Later on, Genesis 13 tells the story of Lot's choice to stay and start a life in "the plain of Jordan that was well watered everywhere, before the Lord destroyed Sodom and Gomorrah, even as the garden of the Lord" (Genesis 13.10). Three verses down, the men of Sodom are for the first time characterized as "wicked and sinners" with no further explanation on the nature of their sins (Genesis 13.13). The "real" story of Sodom and Gomorrah starts with Genesis 18 and is continued in Genesis 19. This latter chapter begins with the arrival of the two angels in the city of Sodom, who are warmly welcomed by Lot. And while Lot offers them a shelter for the night, the other citizens, "the men of Sodom, compassed the house round, both old and young, all the people from every quarter; And they called unto Lot, and said unto him; Where are the men which came in to thee this night? Bring them out unto us, that we may know them" (Genesis 19.4-5). Hearing their violent outcries, Lot offers the Sodomite men his two daughters "which have not known men" to "do ye to them as is good in your eyes: only unto these men do nothing; for therefore came they under the shadow of my roof" (Genesis 19.8).

This is probably the most ambivalent and discussed scene in the Sodom Cycle. The unexplained "wickedness" of the Sodom men who desire to "know the angels" does not allow for a definite answer on the origin of their "sin". However, one of the most wide-spread interpretations of the nature of their wrong-doings argues that the Sodomites' sins can be explained as a lack of hospitality and hostility toward strangers, both actions considered deadly sins in Jewish tradition (see Loader 1990; Newman 1998). "The Sodom and Gomorrah story reflects yet another motif pattern known from extra-biblical literature, that of divine beings who visit a city to

\footnotetext{
${ }^{4}$ As Loader argues, the Yiddish phrase "kid'ld' yada'at" that describes the request of the Sodomite men and is most commonly translated into English as "knowing someone" can, but does not necessarily have to implicate sexual interaction. Throughout the Bible it has only been used 10 times to signify sexual intercourse, while more often it appears as a phrase signifying the desire to literally meet someone (1990: 107). One other way of reading the Sodomite's desire "to know" the angels is to be like them, which can again be compared to Adam's and Eve's desire to be like the gods, ultimately leading to their (sexual and temporal) failure.
} 
test the hospitality of its people and eventually destroy the inhospitable city", write Miller and Hayes (1986: 60).

Similarly, J.A. Loader offers a very interesting interpretation that relates the Sodomites' transgression of the sacred law of hospitality to the subsequent characterization of their sins as "wicked", "unnatural" and finally, "homosexual". According to his analysis, the Sodomites' sexual misdemeanor is not the most important feature of the sin of "sodomy", but rather, the violation of the sacred law of hospitality assumes that position. Their social misdeeds are expressed through the motif of "perverse sex", he writes (Loader 1990: 37). By refusing to welcome their guests and show them due respect, the Sodomites are "making natural intercourse impossible by violating the social fiber of the community as represented by the motif of hospitality" (ibid., 37). In that manner, in Loader's reading, the sin is firstly an act of anti-social behavior that desecrates the basic principle upon which the community is established, leading to a breach of its existing rules, such as the normative flows of time and the "normal" sexual acts and desires. The Sodomites' principal vice is their unacceptable social behavior (whether equated with breaching the law of hospitality, their violence or the desire to become like the immortals) which is then expressed through the motif of perverse sex and leads to the destruction of the future. Thus, homosexuality is a result of their inhospitable behavior, a punishment that is inflicted upon them after they decide to humiliate their guests by not welcoming them in the city. Contrary to the most wide-spread interpretations, the Sodomites' sexuality is not the reason for the angel's visit, but rather the consequence. (Homo)sexuality emerges as the punishment for human fallibility, in a way that is similar to the birth of heterosexuality as a sentence for the desire for knowledge and the committed hubris in the story of Adam and Eve's fall.

Following the continuation of the story, after the Sodomite men refuse Lot's offer, they attempt to enter his house, but the angels blind them so that they cannot find the door. As depicted in the next couple of verses, the angles protect Lot's family as they all escape to the nearest city Zoar, while "Lord rained upon Sodom and upon Gomorrah brimstone and fire from the Lord out of heaven" (Genesis 19.24). The Sodom Cycle and the nineteenth chapter of the Genesis concludes with the mini episode concerning Lot and his daughters. After witnessing the destruction of their world which signifies the end of time as they know it, Lot's two daughters are concerned for the future existence of the family. Therefore, they decide to intervene and save their family "by preserv[ing] the seed of [their] father". The plan is executed during the two following nights. They "make their father drink wine", "go in" and "lay with him" while "he perceived not when [they] lay down, nor when [they] arose" (Genesis 19.31-35). The children born out of this incestuous intercourse save and prolong the existence of Lot's family and that of the entire community. The homosexual sins of the Sodomites destroy Lot's family leading to the end of time, but the incestuous sexual intercourse between Lot and his daughters marks its new start and continues the family line. "Perverse" sexuality thus functions as a motivator of temporal transformations.

In other words, the ambiguously wicked (homo)sexual conduct of the Sodomite men causes their fall and at the same instance ends the linear flow of time, represented by the annihilation of their present and future, and brought on by the fall of 
their city. From there on, the renewal of time, or the beginning of a new epoch is only possible after another instance of a perverse sexual act, depicted through the incestuous episode between Lot and his daughters, whose aim is maintaining the family tree through an un-ceased succession of time. Thus, sinful sexuality stops time and incestuous sexuality begins its flow anew. Describing yet another fall of men as related to an ambiguous, "wicked" and sinful sexual behavior that leads to the "end of time" (symbolized by the destruction of the cities) while at the same moment reviving the flow of life (as the story of Lot and his daughter indicates) the myth of Sodom and Gomorrah can be analyzed as another instance of the Fall.

Starting from this premise, in the following section, I examine the manner in which Proust uses the myth of the fall of Sodom and Gomorrah while developing his own theory of homosexuality. While doing that I am mostly interested in the manner he uses the notion of failure that determines his depiction of sexual and temporal ambivalences. I will address the ways in which the narrative of Sodom and Gomorrah represents the failure of retrieving time and at the same moment brings forth the possibilities of reimagining temporality through the multiplication and diversification of its dimensions. Furthermore, one of the most important axes of my analysis here will focus on the meaning writing assumes when transformed into means of creating temporal heterogeneity through the representation of fallen and sexually perverse activities.

\section{Sex beyond Sex: The Bumblebee, the Orchid and the Snail; or the Curse Race of Inverts}

The opening pages of Sodom and Gomorrah, the fourth volume of Marcel Proust's In Search of Lost Time, where he describes the experiences, life-style and choices of inverts 5 have probably become Proust's "most (in)famous text on homosexuality" (Scheher 1995: 53). Proust's characterization of homosexuals as the "cursed race" still stirs up debates, leading scholars to wonder whether "this representation reflects or subverts conventional moral structures surrounding the subject and the prevailing sexological theory of his time" (Cairns 1997: 43). But while describing this behavior which is called vice "most incorrectly" or "for the sake of linguistic convenience", Proust does not attempt to essentialize the sinful nature of homosexuals (3:18). Rather, following the significance of the social nature of the "sin" implicated in the myth itself, as Loader argued, he is emphasizing a social marginalization as an aspect of the inverts' experience.

Another feature of Proust's theory on homosexuality that is essential for its full understanding is the manner in which he depicts inverts by relying on multitude of botanical and natural metaphors without "the slightest scientific claim to establish a relation between certain botanical laws and what is sometimes, most ineptly, called

\footnotetext{
${ }^{5}$ Commonly used as a general term for "homosexuals" at the time period - this section, as it will become clear from here on, analyzes the nature of homosexuals as "inverts" in Proust's novel.

6 "[A] race upon which a curse is laid and which must live in falsehood and perjury because it knows that its desire, that which constitutes life's dearest pleasure, is held to be punishable, shameful, an inadmissible thing, which must deny its God [...] sons without a mother, to whom they are obliged to lie even on the hour when they close her dying eyes; friends without friendships [...]" (Proust 4:20).
} 
homosexuality" (3:9)7 . According to Gilles Deleuze's interpretation introduced in his study "Proust and Signs" the vegetal metaphor which firstly appears in Sodom and Gomorrah and from then on constantly recurs in all the volumes of the novel serves to primarily illustrate the isolation of the sexes who live forever under Samson's prophecy "the two sexes shall die, each in a place apart", a quote appearing at the first page of the volume. But the separated sexes exist in the same individual, or the homosexual who is here compared to the hermaphrodite snail or plant "which cannot be fertilized except by other hermaphrodites" (Proust 4:4).

Every homosexual encounter is thus transfigured and depicted through a comparison with the fertilizing rituals that occur between bees and flowers. When the narrator compares the sexual intercourse between Charlus and Jupien with the bumblebee that fertilizes the orchid, what he sees in front of him seems instantly beautiful. Charlus the bumblebee seeks Jupien the orchid, and their encounter is itself a "miracle" (Proust 4:38). Embodying the unison of the sexes, inverts are the only real transsexuals. And transsexuality (or the coexistence of the sexes in one body in Proust's vocabulary) is "the ultimate level of the Proustian theory of homosexuality" (Deleuze 2008: 121-22). However, instead of triggering the communication between male and female which coexist in him/herself, the hermaphrodite separates them, although he/she is the one that possesses them. The "cursed" homosexual, self-fertilizing and yet sterile hermaphrodite then produces the two divergent homosexual series that live together and never establish meaningful contact: the daughters of Gomorrah and the sons of Sodom. In such manner, Deleuze contends, homosexuality, by containing both sexes and not being able to effectuate their unison, in Proust's novel is "the truth of love" which wrapped in jealousy, secrets and pain, is always destined to fail (2008: 80-81).

Starting from here and focusing on couple of episodes from Sodom and Gomorrah where these thematic motifs come to the front, throughout this chapter I will address the complex and intermingled relations between the notions of love, failure, homosexuality and temporality. I argue that the homosexual in Proust's vision that unites the two sexes and yet separates them signifies both the failure of the sexes and subsequently, of love, but at the same time it utilizes this failure inner to homosexuality as a motivator in the recapturing of lost times. In doing that, in the remaining pages of this chapter I will focus on Albertine, as a representative of the "Gomorrahian" motif, and through her analyze the impact of failure in narrativizing queer sexualities and nonlinear temporalities in In Search of Lost Times.

\section{4 "I am unable to confer on her retrospectively an identity"}

The depiction of queerness in Proust, as I have been arguing so far, is an elusive narrative strategy, determined by contradictory feelings of self-hate and an urge for

\footnotetext{
${ }^{7}$ Proust's vegetal homosexuality has also caused many debates and divided opinions on the matter. Influential queer theory scholars such as Eve Kosofsky Sedgwick or Leo Bersani have argued that the thematization of homosexuality that invokes comparisons with animal and vegetal sexual hermaphroditism is "sentimental and reductive" or even "banal" (1990; 2007: 216 and Bersani 1987: 24, respectively). Others have stated that "the general metaphor for homosexuality is nature, something as natural as the fertilization of flowers by bees. According to this apology, homosexuality is natural in man because there are so many cases of it in nature" (Scheher 1995: 69).
} 
self-preservation; jealousy and voyeurism; coupled with admiration and a sense of truth and beauty. The case of Marcel's obsession with Albertine, his "Gomorrahian" lover, will here serve as a case-study for the narration of homosexuality in the novel. Depicted not only as a sadistic act, but as a masochistic experience as well, Marcel and Albertine's love story triggers the feelings of jealousy, grief, pain, and suspicion while disrupting the linear normativity of temporal existence.

From the moment Marcel starts to suspect Albertine has same-sex desires and maybe experiences, his jealousy becomes the main source of his actions, as well as his love. His activities in Balbec throughout the volume are determined by his suspicions for Albertine's Gomorrahian desires and his intention to prevent their realization, whether embarking on an unexpected trip just in order to prevent her seeing her girlfriends on the seaside, or going to the Verdurin's dinner party only to inquire whether one of the girls she might want to meet is there. In that way, Albertine never becomes a fully individual character; she is always represented as a part of the group of girls that surround her. As the narrator remarks at one instance, in a sentence that has inspired the title of this subsection, he is "unable to confer on her retrospectively an identity" (Proust 1:905).

Even when she is alone with him, and especially after he starts to develop his ever-growing suspicions, he can never feel her as fully present, or as someone with himself. Albertine's lack of cohesive identity that makes her a never quite reachable and elusive presence is expressed in the ways other characters perceive her, possibly reiterating Marcel's own thoughts on her. When faced with the possibility of Marcel marrying her, his mother says to him: "As a matter of fact, I can't say what I think of Albertine, I don't think of her [...] But at this first stage, I can praise her only by negatives. She is not this: she has not the Rennes accent. In time, I shall perhaps say: she is that" (Proust 4:443, my emphasis). But Albertine never gets the time to surpass this negativity and to be known for something that she is, rather than something she is not.

Albertine, whom the narrator can only perceive through her undefined and unreachable elusiveness, and whose queer desires and practices condemn her to "no future" can be analyzed, following Lee Edelman's suggestions, as the embodiment of queerness itself (2004:11). For Edelman, queerness opposes the all-encompassing temporal, social and political order. As such, queerness cannot be reconciled with the notion of heteronormativity ${ }^{8}$, embodied in a normative social order through the figure of the ideal citizen who will insure the endless coming of the productive future through heterosexual reproductive practices (Edelman 2004: 13-15). The figure of the child in Edelman's work becomes the bearer of "reproductive futurism". On the other hand, the adult who opposes the reproduction of social as well as temporal futurity by disturbing her/his identity ("for queerness can never define an identity, it can only disturb one", says Edelman (2004: 17)) is definitely a queer one. Albertine, who is forever enclosed in a time that cannot be reached, having no conceivable past, or an awaiting future, seems to me a perfect symbol for the ideal of queerness Edelman opposes to the figure of the "heteronormative child". One of

\footnotetext{
${ }^{8}$ See more about the normalization of heteronormativity - the belief that heterosexuality is the default, "natural", original mode of sexual orientation and being in Warner, Michael. Introduction: Fear of a Queer Planet (1991).
} 
the budding girls, or the young woman with the bad reputation, the captive of the fugitive, Albertine does not have the strength to move time backwards or forwards. She exists as a symbol of an ideal future-less queerness.

In further developing this claim, I will now focus on one instance that nicely illustrates Albertine's embeddedness in a perverse flux of time and sexuality - related to the manner in which the narrator experiences his love towards Albertine as a vehicle for retrieving past times after his grandmother's death. The awakened grief and gilt over his grandmother's death seem to arouse Marcel's sexual desires for Albertine of the past, as much as for the young pages, bell-boys and hall-porters for the Balbec hotel (Proust 4: 233-236). In this sense, it is not Albertine herself whom he desires, but rather the past times he had spent in her company, in those happy days when his grandmother was alive. She becomes the instrument through which his body longs not only to relive the past but to completely replace it with the present, and make it the future through experiencing a sexual encounter with her. In that way, sexual desire here is not directed at Albertine, but at the narrator's past self that he wishes to restore, almost implying a a sodomitical and an autoerotic relationship between Marcel and his former self, whose only purpose would be to bring back the past.

Marcel seeks to experience temporal change through indulging in queer sexual activities. The encounter between past and present that informs the future is imagined as emerging through a sexual act. This situates the disruption of chrononormativity as resulting from what Freeman calls a "tactile meeting" that enables "times touching each other" (2010:110). The meeting between past, present, and future times is here configured as an erotic experience. But the temporal flexibility or the disruption of time's linearity, at least in Marcel's thought and hopes, certainly depends on the feasibility of attaining queer sexual pleasures. The sexual encounter with Albertine that is imagined as a sodomitical sex act with his own past self is intended to bring the past, present, and future into new conjunctures. Albertine's body, or rather, the narrator's body constitutes the moment of pure "touching" of the past and the present through sexual contact. The jealousy directed towards Albertine, as the narrator himself is aware on many occasions is actually a result of "the selfish exaltation of the lover who is in love with his own love", and the consequence of his efforts to control and capture not her, but his own feelings (Kristeva 1998:26). Furthermore, this justifies my proposed reading of his illusionary desire towards Albertine as a form of sodomitical relationship with himself. What is more significant for me here, is the way in which this queer relationality with oneself is transformed into a means that has a power to alter normative timelines.

Embodying Edelman's queer non-futurity, Albertine signifies the annihilation of time, or a time standing still, a past-less and future-less existence. Therefore, she is certainly not the means through which the narrator can capture lost time. Instead, she is the one through whom the failure of grasping the past is being rendered. Interestingly, in such manner, Albertine's queer negativity that seemingly can only mark the failure of time is transformed into an impetus for discovering new ways in which past, present and future can interact, thus indicating the real-life impossibility of Edelman's project in whose work queer temporality is always condemned to a one-dimensional present-ness. 
That is why, in this instance, when considering the complex temporal amalgamations between past, present and future that mark Marcel's queer temporality, I find Muñoz's thinking of queer time more suitable than Edelman's. José Esteban Muñoz's utopian temporal project, unlike Edelman's, does not abolish the future, or rather, the relation between queerness and futurity, but instead imagines queerness as a "temporal arrangement in which the past is the field of possibility in which subjects can act in the present in the service of new futurity" (2007:156). This paradigm presupposes the utilization of one temporal line in the complexification of all others, as is the case of Albertine's disappearance and death in In Search of Lost Times.

Proust, therefore, does not kill off Albertine without a reason: he uses her death that erases her from Marcel's life as a motivator that provides him the chance to oppose the progress of a sexually and temporally normative timeline and discover new modes of queering time. "It is the signs of love that implicate lost time in the purest state", writes Deleuze (2008: 18). In this case, the death of the grandmother acts as a sign of the forever lost time and motivates the search for regaining the plenitude of times. The worldly signs, the signs of love, and the sensuous signs might be the signs of lost time ${ }^{9}$, indicating the failure to ever retrieve the wasted time, but they are necessary as the stepping stones towards the signs of art that have the power to reimagine and regain time. Albertine, the beloved one, causes suffering and pain for the narrator, but it is that pain that leads the metamorphosis of the narrator to a writer that is able to recapture time. It is necessary for him to decipher the signs of love and lose his time in order to regain it in all its multiplicity through art.

Therefore, Proust's novel is not completely oriented towards the past through the search of lost time, but rather multiples and complicates the various timelines in order to regain time, not by going back to the past, but by mingling the past, present and the future in a manner that defies temporal linearity. The absolute regained time at the end consist of all times, creating a sphere in which all timelines are amalgamated, as in Muñoz's model. The main events that stimulate the search for lost time and the subsequent artistic recuperation are failed, homosexual, guilt-driven and jealous love. The Search consists of series of discontinuous sexual and temporal failings and attempts for their transformation into sources of productivity. Failure of time, love and sex result not only in the loss of time, but drives the desire to recapture time, and from there on, directly participates in the creative refiguring of time's irreversibility.

According to Scheher, in Proust's work homosexuality serves as both a determining factor for interpretation and general hermeneutics (1995: 34). His reading indicates that every theme of the novel is determined and can be analyzed through its explicit connections with homosexuality. Or rather, the representation of homosexuality colors the rendering of every thematic sequence of the novel, positing queerness itself, as Scheher claims, as a hermeneutical device through which all

\footnotetext{
${ }^{9}$ The search of lost time, according to Deleuze, is a search for truth which the narrator seeks through the interpretation of four kinds of signs: the worldly sings, the signs of love, the sensuous sings and the signs of art. Each kind of sign has its own timeline, but at the same moment intersects and participates in the times of line that the other sings develop. Therefore the multiplicity of timelines introduced by the sings clearly indicates the plenitude of time itself, making the search for the truth through the deciphering of sings always a temporal one, or a search for the truth of time (2008: 15-17).
} 
other topics can be addressed. The narrativization of temporality is therefore one of the themes of the novel that can be interpreted thorough this general homosexual, or rather, queer hermeneutics. I hope that my analysis in the previous sections has managed to illustrate - through the figure of Albertine - exactly that claim: time and its failure in Sodom and Gomorrah is structured and narrativized by queerness. In the concluding pages of this essay I will focus on the dynamics of the processes of queer narrativization, by looking into how in Proust's novel writing becomes the field through which the narrator/writer fully uncovers the potentials of queering time.

\section{The Lover Becomes a Writer}

Failure experienced as jealousy, grief, loss, pain or suffering and intertwined with the existence of same-sex desires profoundly determines the narrativization of time in Proust's Sodom and Gomorrah. However, failure's negativity is here reimagined as an instrument that initiates the skewing of prescriptive and regulative sexual behaviors. Marcel's desire to capture and fully control the future with Albertine and to bring back the innocent past he believes he enjoyed with her erupts directly from his suspicions that she might have engaged in same-sex practices. Only after the inevitable failure of these plans that seek to restore a regulating and fixed flow of time, Marcel discovers that process of writing through which he is able to manipulate time's dimensions. This seems to indicate that time can never be only linear and normative and every desire to perceive it and represent it in such manner is ultimately a failure. The failure of regaining past time here is utilized as a stimulator that leads the transformation of queer negativity into a means for disturbing time's linear normativity through the act of writing. Instead of treating the past as a material for achieving linear progress or fully abolishing it (neither of them possible), the narrator is now able to engage with it as deeply as he does with the present he lives in order to create the most desirable future.

Albertine's queerness brings her "no future". However, this kind of queer temporality or better said, annihilation of temporality by its enclosement in a sphere of perpetual present that abolished both present and future induced by queer Gomorrahian desires is only appropriate as an interpretative mode while analyzing Albertine's character. Caught only in the eternal present with no possible implications on the future or achievable modifications on the past, Albertine's queer temporality and sexuality does not seem to be replicating the Fall pattern. The ultimate queer in Edelman's view that was hereby analyzed through Albertine who has no implications or rights on the future is equated with pure negativity. In such way, queer temporality when deprived from past and future is no temporality at all. Though useful for analyzing Albertine's personal temporality that negates both the past and the future, I believe that Edelman's model of queer temporality is not applicable when dealing with Proust's complex intertwining of past, present and future.

In the previous section, I looked at the impossibility of bringing back the past as the past and thus merging it with the present that would simply reinstate time's normative order is repudiated through the unfolding of Albertine's story. The narrator's desire to produce a chrononormative timeline by capturing Albertine and ensuring their future in the end fails. This failure is reconfigured as productive because at the 
same moment it makes him realize that the queer mingling of present, past and future is only possible when their features are creatively transformed in the sphere of writing. The most productive manner of employing Albertine's queer negativity in my own analysis is by addressing the temporal annihilation she invokes as a means for utilizing the potential of this failure in developing new methods of grasping the past, or reinventing the present and the future, addressed in their complexity through Muñoz's utopian temporal thinking.

The failure of grasping or annihilating time though the futility of establishing a meaningful relation with his beloved or with his own self, is here productively transformed in an impetus for writing. Writing or literature becomes a sphere or better said an instrument through which Marcel is able to grasp, convey and transform the sexual and temporal failures into something worth saving - his own story. Writing redeems life's sexual and temporal failability and celebrates it while literally creating new universes only in these universes is the conjunction of past, present, and future made possible through the invocation of queer sexual pleasures. Writing affords the sort of transcendence the narrator needs in order to employ the hidden potentials of negative effects, such as jealousy, guilt, loss, grief or failure.

Only literary narratives are able to recuperate time, transforming the novel into a "story of redemption through art or of the recuperation of essence through writing" (Scheher 1995: 36). The artist, or the writer, "has the revelation of an original time, coiled [...] embracing simultaneously all its series and dimensions" writes Deleuze. Through writing, the author can experience the "true sense of the expression 'time regained', which is understood of the signs of art (2008:46). Art and writing capture time in all its multifacetedness.

Fallen homosexuality is nothing but productive, converting the sterility and negativity of jealousy, pain and suffering into "flowers, butterflies, pages and books" (Scheher 1995: 81). It is the possibility and reality of failure and disappointment as experienced through homosexual, jealous or sadomasochistic acts that complexifies and diversifies the lines of time. By wanting to transmit the past as the past, the jealous lover is cursed to anticipate and wait for a time that will never arrive. But his failure enables him to retrieve a time in which the past, the present, and the future will intermingle, inhabiting the same dimension. By using both Edelman's model of queer negativity - in analyzing the Albertine's character; and Muñoz's utopian paradigm - in addressing the multitemporal world writing creates out of failure and negativity, I hope to have shown the various uses of queer failure as contained in the Myth of the Fall pattern. At the same time, I was also aiming to show how these two different and even opposing ways of thinking about queer temporality can intertwine with each other: queer failure can signify future-less existence, but it can also act as an impetus for an utopian intermingling of all temporal dimensions.

The homosexuality of the fallen race that caused the fall of the cities of the plain, destroying their future is the carrier, or rather, the motivator of differentiation that creates the constant flow of movements that disrupts sexual, as well as temporal sameness. The fallibility of the cursed race and the sinful nature of sex itself, present since the first Fall and maybe most vividly represented through the fall of Sodom and Gomorrah, serves as the starting point for the narrator in his positing of 
the creative process of writing as the means of discovering productive and fertilizing techniques that advance his search of lost time.

\section{Bibliography}

Barrows, A. (2010). The Cosmic Time of Empire: Modern Britain and World Literature. London and Los Angeles: University of California Press.

Bauman, Z. (2000). Time and Space Reunited. Time and Society 9 (2/3): 171-185.

Bersani, L. (1987). Is the Rectum a Grave? October, AIDS: Cultural Analysis/Cultural Activism 43: 197-222.

Bradbury, M., and McFarlane, J. (1991). Modernism: 1890-1930. A Guide to European Literature. London: Penguin Books.

Cairns, L. (1997). Homosexuality and Lesbianism in Proust's Sodome et Gomorrhe. French Studies, 51 (1): 43-57.

Campbell, J. (1962). The Masks of God. Vol. 3. Occidental Mythology. London: Secker \& Warburg.

Deleuze, G. (2008). Proust and Signs. London: A\&C Black.

Dillistone, F. W. (1965). The Fall: Christian Truth and Literary Symbol. Comparative Literature Studies, 2 (4) [Literature and Religion]: 349-362

Edelman, L. 2004. No Future: Queer Theory and the Death Drive. Durham: Duke University Press.

Eliade, M. (1987). History of Religious Ideas: V. 1: From the Stone Age to the Eleusinian Mysteries. Chicago: University of Chicago Press.

Eng, D. L., Halberstam, J., and Muñoz, J.E. (eds.) (2005). "What's Queer About Queer Studies Now?" Social Text 23 (3/4 84-85): 1-17.

Freeman, E. (ed.) (2007). Queer Temporalities, GLQ: A Journal of Lesbian and Gay Studies, 13(2-3): 177-195.

Freeman, E. (2010). Time Binds: Queer Temporalities, Queer Histories. Durham: Duke University Press.

Kern, S. (2003). The Culture of Time and Space, 1880-1918: With a New Preface. Boston: Harvard University Press.

Kristeva, J., and Guberman, R. (1998). Time and Sense: Proust and the Experience of Literature. New York: Columbia University Press.

Loader, J. A. (1990). A Tale of Two Cities: Sodom and Gomorrah in the Old Testament, Early Jewish and Early Christian Traditions. Leuven: Peeters Publishers.

Muñoz, José Esteban. (2009). Cruising Utopia: The Then and There of Queer Futurity. New York: New York UniversityPress.

Miller, J. M. and Hayes, J. H. (1986). A History of Ancient Israel and Judah. London: Westminster Press.

Newman, J. H. (1998). Lot in Sodom: The Post-Mortem of a City and the Afterlife of a Biblical Text. In Evans, C.A. Sander, J.A. (eds.) The Function of Scripture in Early Jewish and Christian Tradition. 34-45. Sheffield: Sheffield Academic Press.

Otten, T. (1982). After Innocence: Visions of the Fall in Modern Literature. Pittsburgh: University of Pittsburgh.

Proust, M. (1992-93). In Search of Lost Time, 6 vol. Mongrieff C.K.S. Klimartin, T. (trans.). Enright. D.J (rev). New York: The Modern Library New York.

Scheher, L. R. (1995). The Shock of Men: Homosexual Hermeneutics in French Writing. Palo Alto: Stanford University Press.

Sedgwick, K.E . (1993). Tendencies. Durham: Duke University Press. 
Sedgwick, K.E. (2007). Epistemology of the Closet. Updated with a New Preface. Los Angeles: University of California Press.

The Bible: Authorized King James Version. 2008. Oxford: Oxford University Press.

Warner, M. (1991). Introduction: Fear of a Queer Planet, Social Text, 29: 3-17. 
